however, Pelham, who might not have access to the Arabic language, ${ }^{3}$ arranged his material in a rather haphazard manner, making it appear like a puzzle to which the clue is missing. A better bargain is Vali Nasr's The Shi'a Revival: How Conflicts within Islam Will Shape the Future. ${ }^{4}$

\title{
Notes
}

1. Christoph Marcinkowski, Shi'ite Identities: Community and Culture in Changing Social Contexts, Freiburg Studies in Social Anthropology 27 (Berlin: LIT Verlag, 2010), 81-2.

2. On p. 205, Pelham quotes from al-Sadr's Lamhah fiqhiyyah: "Islamic theory rejects monarchy as well as the various forms of dictatorial government; it also rejects aristocratic regimes and proposes a form of government, which contains all the positive aspects of the democratic system," a translated passage, which, according to Pelham, is found in Sama Haddad, The Development of Shi 'ite Islamic Political Theory, for which no complete bibliographical reference has been provided by him and which couldn't be traced by this reviewer otherwise.

3. In relation to this, I am refraining here from pointing out all of the countless errors in terms of transliteration, referring here only to "al-Qaddisiyah" instead of "al-Qādisiyyah" (p. 6), "Saladin al-Ayyubbi" instead of "Salāḥ al-Dīn al-Ayyūbī" (p. 8), and "Nidhamiya" instead of "Nizāāmiyyah", while on the same page referring to Nizāam al-Mulk (the founder of the Nizāmiyyah colleges) (p. xi).

4. New York and London: W.W. Norton and Company, 2007.

\section{Abdulkader Thomas (ed.), Sukuk}

(Kuala Lumpur: Securities Commission Malaysia, Sweet and Maxwell Asia, 2009), 433 pp. ISBN: 978-967-5040-21-2

\section{Abdul Karim Abdullah (Leslie Terebessy) International Institute of Advanced} Islamic Studies (IAIS) Malaysia

This book, which contains a foreword by Tan Sri Sheikh Ghazali Haji Abdul Rahman, the Chairman of the Shari' 'ah Advisory Council of the Securities Commission of Malaysia, has been introduced by the Securities Commission of Malaysia under the Islamic Capital Market series. It is the first of six volumes. It consists of 16 chapters and several case studies, figures, tables and a list of abbreviations. The objective of the book - published before the effects of the recent global financial and economic crisis were felt in the Islamic capital markets - is to introduce șukuk to the general reader.

In the preface ("Foundation and Framework") Iqbal A. Khan writes that the "distinguishing feature of sukuk and Islamic finance [...] is that its tenets are based on the principles of fairness". He emphasises "certainty" and "transparency" in contracts, the sharing of "business risks and returns" (losses are not mentioned), and "direct participation in real asset performance". He adds that, șukūk are "deemed equivalent in structure to asset-backed trust certificates rather than bonds", which 
are "contractual debt obligations" (p. ix). The great majority (90 per cent) of the $s u k \bar{u} k$, however, are not 'asset-backed' but rather 'asset-based'. The difference is important in so far as asset-backed șukūk confer legal ownership of the underlying assets on the șukūk holders while asset-based șukūk do not. (Asset-based șukūk only confer 'beneficial' ownership.) In addition, it is somewhat puzzling that one finds no mention here of the fact that șukuk need to be first and foremost interest or $r i b \bar{a}$-free. Indeed, the expression 'interest' or $r i b \bar{a}$ cannot found be anywhere in the preface. The index likewise lacks an entry for ribā or interest.

In Chapter 2, "Sukuk and the Capital Markets", Shabnam Mokhtar, Saad Rahman, Hissam Kamal, and Abdulkader Thomas acknowledge that, "sukuk are generally structured to have bond-like characteristics" (p. 19). In relation to the sale of the dividend-generating assets by originators to the sukūk holders, the authors state that in a "true sale" the asset is "separated from the accounting and bankruptcy estate of the originator $[\ldots]$. In a true sale transaction, the ultimate investor will enjoy the risk and reward, or have the right of disposal of the underlying assets" (p. 20).

The authors could have added that in a true sale investors not only have the "right of disposal of the underlying assets", but come into full, legal ownership of those assets. This sometimes remains unclear, thus causing a lack of transparency about precisely what kind of ownership șukük holders actually have. The type of ownership $s u k \bar{u} k$ holders have becomes especially relevant at a time of distress. Investors in asset-backed șukūk are legal owners of the underlying assets. This is not the case with investors in asset-based șukūk. With asset-based șukukk, the ownership of the underlying assets remains, in one form or another, with the originators. Holders of asset-based sukūk enjoy merely 'beneficial' ownership. They are owners of the usufruct produced by the assets, but not the assets themselves. At a time of distress (default), the investment of the holders of asset-backed șukuk is protected. That of the holders of asset-based șukük is not. This is a crucial difference.

In Chapter 6 ("Basel II and Sukuk"), Natalie Schoon observes that șukūk which confer "beneficial ownership" allow the underlying assets "to be considered as collateral (asset-backed sukuk) or not (asset-based)" (p. 114). This statement is only partly true. The fact is that 'beneficial ownership' does not allow șukūk to be considered as 'asset-backed' but only as 'asset-based'. For the șukūk to be considered as asset-backed, a true sale of the underlying assets to the șuku $k$ holders would have to have taken place. Clearly, this did happen in the vast majority (90 per cent) of the șukūk issued, where șukūk holders can claim ownership only of the dividends generated by the underlying assets but not of the assets themselves. Should the issuer default on paying the dividends, holders of asset-based $s u k \bar{u} k$ have no legal recourse to the assets because they do not own them. Their only recourse is to the originator. Unlike holders of asset-backed șukuk , holders of asset-based $s u k \bar{u} k$ are 
not in a position to recover their capital by selling the underlying assets as the ownership of the assets has remained with the originators.

The difference between asset-based and asset backed șukuk is important, as significant implications follow for investors' protection at a time of distress. The investment of the holders of asset-backed șukuk is protected against loss, as they are the legal owners of the assets. Should a default occur, they can recover their capital investment by selling the assets in the open market. They can do this because they are the legal owners of those assets. Holders of asset-based șukuk , by contrast, cannot sell the underlying assets to recover their investment, as they are merely the 'beneficial' but not the legal owners of the assets. Thus, holders of asset-based $s u k \bar{u} k$ are exposed to the risk that they might lose their investment. From a legal point of view, the status of the holders of asset-based șukuk is no different from that of unsecured creditors.

In Chapter 16 ("How Expansive Are the Frontiers") Rodney Wilson discusses some "unresolved issues" (p. 335). However, while we find optimism about "where the industry is going", a number of pressing issues receive little or no attention. One of these is investor (sukūk buyer) protection. Another is the question of whether șukuk should continue replicating conventional bonds or be structured as genuine PLS instruments.

In general, the book raises more questions than it answers. Let us hope the next volume will rectify these shortcomings.

\section{Bertrand de Speville, Overcoming Corruption: The Essentials}

(Kuala Lumpur: Research for Social Advancement, 2010), 112 pp.

ISBN: 978-967-5942-03-7

\section{Zarina Nalla International Institute of Advanced Islamic Studies (IAIS) Malaysia}

The title of the book is very reflective of its length and style: brief and succinct almost like a handbook, it is meant for anticorruption decision-makers from the developed and developing world who are too busy to read laborious pieces on the subject.

The author, an English law barrister who went to Hong Kong in 1981, became Solicitor General prior to his appointment as Commissioner of the Independent Commission Against Corruption (ICAC) of Hong Kong from 1992 to 1996, just before the city was returned to China. He turned ICAC into a leading anti-graft body admired by international observers. In London, where he is currently based, he became adviser to the Council of Europe's Multidisciplinary Group on Corruption from 1997 to 2003. He is consulted by a number of international development 